\title{
Salermide down-regulates sirtuin proteins to induce human cancer cell apoptosis
}

\author{
Asha Leisser, Michael Wolzt ${ }^{*}$, Angela Storka \\ From 17th Scientific Symposium of the Austrian Pharmacological Society (APHAR). Joint meeting with the \\ Hungarian Society of Experimental and Clinical Pharmacology (MFT) \\ Innsbruck, Austria. 29-30 September 2011
}

\section{Background}

The $\mathrm{NAD}^{+}$-dependent family of sirtuin proteins (SIRT1-7), is involved in cell apoptosis and senescence. Salermide is a potent inhibitor of SIRT1 and SIRT2 and can induce tumor-specific cell death in selected human cell lines. In this study we investigated salermide's apoptotic effect in a wide range of other human cancer cell lines and its antiproliferative potential in combination with cisplatin.

\section{Methods}

Seven different cancer cell lines (SKOV-3, MKN45, MKN28, N87, FaDu, NuLi1, Jurkat) were treated with salermide $(1 \mu \mathrm{M}-0.1 \mathrm{nM})$ for 24,48 , and 72 hours and assessed for cell viability. Three cell lines (SKOV-3, N87, Jurkat) were selected for combination therapy with salermide and cisplatin $(30 \mu \mathrm{M})$. In order to characterize salermide's proapoptotic pathway SIRT1, SIRT2, pAKt, p53, acetyl-p53 and Nampt (nicotinamide phosphoribosyltransferase) were determined in SKOV-3 and Jurkat cells by Western blotting.

\section{Results}

Salermide yielded greater dose-dependent apoptotic effects in Jurkat, SKOV-3 and N87 cells than in the other cell lines, with most potent effect after $48 \mathrm{~h}$ of incubation. The anti-proliferative activity was associated with a $\mathrm{G}_{0}-\mathrm{G}_{1}$ cell cycle arrest. SIRT1 and SIRT2 protein were down-regulated after $48 \mathrm{~h}$ and $72 \mathrm{~h}$. This was accompanied by a down-regulation of pAKT, p53 and Nampt. Acetyl-p53 levels were not consistent across cell

\footnotetext{
* Correspondence: michael.wolzt@meduniwien.ac.at Department of Clinical Pharmacology, Medical University of Vienna, 1090 Vienna, Austria
}

types. Cisplatin exerted synergistic effects with salermide in all cell lines and reduced cell viability up to $50 \%$.

\section{Conclusions}

Salermide-induced apoptosis is cell line-dependent and more effective in slow-proliferating (SKOV-3) and hematologic (Jurkat) cancer cells. The synergism with cisplatin implies a potentiating effect of this sirtuin inhibitor as add-on in clinical cancer therapy.

Published: 5 September 2011

doi:10.1186/1471-2210-11-S2-A49

Cite this article as: Leisser et al:: Salermide down-regulates sirtuin proteins to induce human cancer cell apoptosis. BMC Pharmacology 2011 11(Suppl 2):A49.

\author{
Submit your next manuscript to BioMed Central \\ and take full advantage of: \\ - Convenient online submission \\ - Thorough peer review \\ - No space constraints or color figure charges \\ - Immediate publication on acceptance \\ - Inclusion in PubMed, CAS, Scopus and Google Scholar \\ - Research which is freely available for redistribution \\ Submit your manuscript at \\ www.biomedcentral.com/submit
}

\section{Biomed Central}

C 2011 Leisser et al; licensee BioMed Central Ltd. This is an open access article distributed under the terms of the Creative Commons Attribution License (http://creativecommons.org/licenses/by/2.0), which permits unrestricted use, distribution, and reproduction in any medium, provided the original work is properly cited. 